\title{
Super-Stereotypy I: Enhancement of a Complex Movement Sequence by Systemic Dopamine D1 Agonists
}

\author{
KENT C. BERRIDGE ${ }^{1 *}$ AND J. WAYNE ALDRIDGE ${ }^{1,2}$ \\ ${ }^{1}$ Department of Psychology, University of Michigan, Ann Arbor, Michigan 48109-1109 \\ ${ }^{2}$ Department of Neurology, University of Michigan, Ann Arbor, Michigan 48104-1687
}

\begin{abstract}
KEY WORDS dopamine movement sequence; grooming stereotyped movement; fixed action pattern; basal ganglia striatum; nigrostriatal dopamine; D1 receptor; D2 receptor; ACTH; peptide; Tourette's syndrome; Parkinson's disease; SKF 38393; SKF 82958; quinpirole
\end{abstract}

\begin{abstract}
Peripheral administration of D1 dopamine agonists elicits grooming behavior from rodents. The present study examined grooming behavior and the relative probability and stereotypy of a natural sequence of grooming movements (called a syntactic grooming chain) that follows a predictable fixed pattern of serial order. We compared the amount of grooming behavior vs. the stereotypy of sequential patterns after peripheral administration of either a partial D1 agonist (SKF 38393; 2.5, 5.0, 10 , $20 \mathrm{mg} / \mathrm{kg}$ ), a full D1 agonist (SKF 82958; 0.1, 0.2, 0.5, $1.0 \mathrm{mg} / \mathrm{kg}$; i.p.), a D2 agonist (quinpirole; $5.0,10 \mathrm{mg} / \mathrm{kg}$ ), or ACTH $(2.0,5.0 \mathrm{mg} / \mathrm{kg}$ ). There was a dissociation between the elicited grooming amount, the pattern frequency, and the pattern completion or sequential stereotypy after these drugs. Quinpirole and ACTH both reduced the likelihood that the sequential pattern would be completed in the normal pattern (and reduced the overall amount of grooming). Administration of either SKF 38393 or SKF 82958 increased the tendency to engage in complex stereotyped sequential patterns of grooming (even though only the partial D1 agonist increased the total amount of grooming). In addition, SKF 38393 increased the sequential stereotypy of the already-stereotyped pattern itself (as measured by the probability of completing the stereotyped sequence once it began). Thus, dopamine D1 receptor activation appears to contribute to a kind of sequential super-stereotypy in which a complex, stereotyped behavioral sequence is initiated more frequently and more often goes to completion. Synapse 37:194-204, 2000. $\odot 2000$ Wiley-Liss, Inc.
\end{abstract}

\section{INTRODUCTION}

Grooming behavior in rodents is produced by activation of dopamine D1 receptors (we will use D1 to refer to the class of $\mathrm{D}_{1}$ and $\mathrm{D}_{5}$ dopamine receptors activated by most D1 agonist drugs, and D2 to refer to the class of $\mathrm{D}_{2}, \mathrm{D}_{3}, \mathrm{D}_{4}$ receptors activated by most $\mathrm{D} 2$ agonists). Excessive grooming is elicited from rats by peripheral administration of dopamine D1 agonists (Deveney and Waddington, 1995, 1997; Downes and Waddington, 1993; Eliam et al., 1992; Page and Terry, 1997; Phillips et al., 1995; Starr and Starr, 1986; Trampus et al., 1993; Wachtel et al., 1992; White et al., 1988), and excessive grooming is blocked by D1 antagonists (Molloy and Waddington, 1984; Van Wimersma Greidanus et al., 1989). Excessive grooming is also elicited by central administration of ACTH and other peptides (Dunn, 1988; Dunn and Berridge, 1990; Dunn et al.,
1984, 1987; Gispen et al., 1975; Isaacson and Thomas, 1986; Kulkosky et al., 1988; Moody et al., 1988; Piggins and Merali, 1992), an apparently related phenomenon since it is blocked by dopamine antagonists, especially D1 antagonists (Cools et al., 1978, 1988; Guild and Dunn, 1982; Isaacson et al., 1983; Van Wimersma Greidanus et al., 1989; Zhang et al., 1994). Mice with dopamine-related mutations, especially related to dopamine D1 receptors, similarly have impairments of grooming behavior (Bolivar et al., 1996; Coscia and Fentress, 1993; Cromwell et al., 1998; Drago et al., 1994).

\footnotetext{
Contract grant sponsor: National Science Foundation; Contract grant number: IBN 9604408; Contract grant sponsor: National Institutes of Health; Contract grant number: NS31650.

*Correspondence to: K. C. Berridge, University of Michigan, Psychology Department, Ann Arbor, MI 48109-1109. E-mail: berridge@umich.edu

Received 3 June 1999; Accepted 20 October 1999
} 
Repetitive behavioral stereotypy is another consequence produced by dopamine receptor agonists, especially by D2 agonists (although D1 receptors also have been implicated in repetitive stereotypy) (Adani et al., 1991; Cools et al., 1989; Cooper and Dourish, 1990; Delfs and Kelley, 1990; Eilam and Golani, 1990, Eilam et al., 1989; Randrup and Munkvad, 1974; Robbins et al., 1990; Sirkin et al., 1982; Sullivan et al., 1992; White et al., 1988). The induction of repetitive stereotyped movements, such as simple jaw movements, licking, gnawing, rearing, locomotion, or snout contact with a substrate, is typically viewed as different from excessive grooming. Simple repetitive stereotypy produced by drugs usually involves just one or two movements that are repeated in a perseverative fashion (Dickson et al., 1994; McKenzie et al., 1984; Sirkin et al., 1982). Or, somewhat more complexly, simple locomotion movements may be used to follow complex but perseverative paths after dopamine agonists (Adani et al., 1991; Cools et al., 1989; Eilam and Golani, 1990; Eilam et al., 1989; Whishaw and Dunnett, 1985).

Both repetitive stereotypy and locomotion are different from excessive grooming, in which many actions are employed in various order (e.g., paw stroke movements, licking of various body parts, etc.). Excessive grooming induced by the application of dopamine D1 agonists has sometimes even been called "non-stereotyped" grooming, perhaps to distinguish it from repetitive stereotypy (Marin and Chase, 1995; Marin et al., 1996; Parashos et al., 1990). That implies excessive grooming might be normal in terms of its pattern, although it also has been suggested that excessive grooming may have a different internal time structure from normal grooming (Bressers et al., 1995).

A more complex form of stereotyped behavior than single-movement stereotypy is the subject of investigation in this paper. Stereotyped behavior can include more than one or two movements as long as the behavior is predictable (Attneave, 1959). A highly predictable sequential pattern is more stereotyped than an unpredictable sequence, even if the two sequences contain the same number of elements. For example, the counting sequence $0,1,2,3,4,5,6,7,8,9,0,1,2,3,4,5,6,7,8,9 \ldots$ is far more stereotyped than a random selection of 10 digits. Stereotypy, in other words, can refer to the strength or predictability of a sequential pattern, independent of the number of movement types (Attneave, 1959; Cooper and Dourish, 1990; Fentress, 1968; Lawrence and Rushen, 1993). There are many patterns or sequential rules that have been identified in rodent grooming behavior (Berridge, 1990; Berridge et al., 1987; Bolles and Woods, 1964; Bressers et al., 1995 Fentress, 1972, 1977; Fentress and Stilwell, 1973; Richmond and Sachs, 1978; Spruijt et al., 1992), some of which change in stereotypy after neural manipulations (Berridge, 1989a,b; Berridge and Fentress, 1987a,b; Berridge et al., 1987; Berridge and Whishaw, 1992; Cromwell and Berridge, 1996; Fentress, 1973; Fentress and Stilwell, 1973). This makes grooming behavior useful for studying complex sequential stereotypy.

The most sequentially stereotyped pattern within grooming behavior is a highly predictable sequence of up to two dozen movements that occurs several times per minute during normal grooming (Fig. 1). The pattern has been called a "syntactic chain" of grooming movements because it connects the movements into four sequential phases that follow a syntactic or lawful pattern: small rapid strokes by both paws around the nose are followed by single strokes made by one or the other paw, then by large strokes by both paws over the entire face, and then by body licking, all within 5 seconds (Aldridge and Berridge, 1998; Berridge, 1990; Berridge and Fentress, 1986; Berridge et al., 1987). During a syntactic chain by rats, mice, and other rodents, the pattern is stereotyped in terms of the order, number, size, and speed of each movement. Once the pattern begins, it can be predicted to go all the way to the end with 80 to $90 \%$ accuracy for normal rats (Berridge et al., 1987).

The sequential pattern of syntactic grooming chains is coded by the electrophysiological activity of neostriatal neurons (Aldridge and Berridge, 1998; Aldridge et al., 1993). The behavioral strength of the pattern also depends causally on neostriatal function, and is disrupted by neostriatal lesions (even if grooming movements themselves are spared) (Berridge and Fentress, 1987b; Berridge and Whishaw, 1992; Cromwell and Berridge, 1996). Specifically relevant to dopamine, the pattern depends on neostriatal dopamine receptors, since it is disrupted after 6-hydroxydopamine lesions (6-OHDA) of nigrostriatal projections in rats, and is disrupted also in mutant mice that lack dopamine D1-A receptors (Berridge, 1989b; Cromwell et al., 1998).

Those previous studies showed that the pattern could be impaired by disruption of nigrostriatal dopamine systems. The purpose of this experiment was to examine whether the pattern conversely could be enhanced by dopamine receptor activation. We compared the effects of peripheral administration of dopamine agonists on this predictable pattern and on grooming behavior in general. Experiment 1 compared the effects of a D1 agonist (SKF 38393) and a D2 agonist (quinpirole). Because a further purpose of this study was to prepare for a comparison of excessive grooming elicited by central administration of the same drugs Berridge and Aldridge, pages 205-215, this issue), ACTH-(1-24) was also included. Experiment 2 compared the effects of the partial D1 agonist, SKF 38393, to those of a full D1 agonist, SKF 82958.

\section{EXPERIMENT 1 Methods}

The amount of grooming behavior is usually measured in terms of the number of seconds spent groom- 


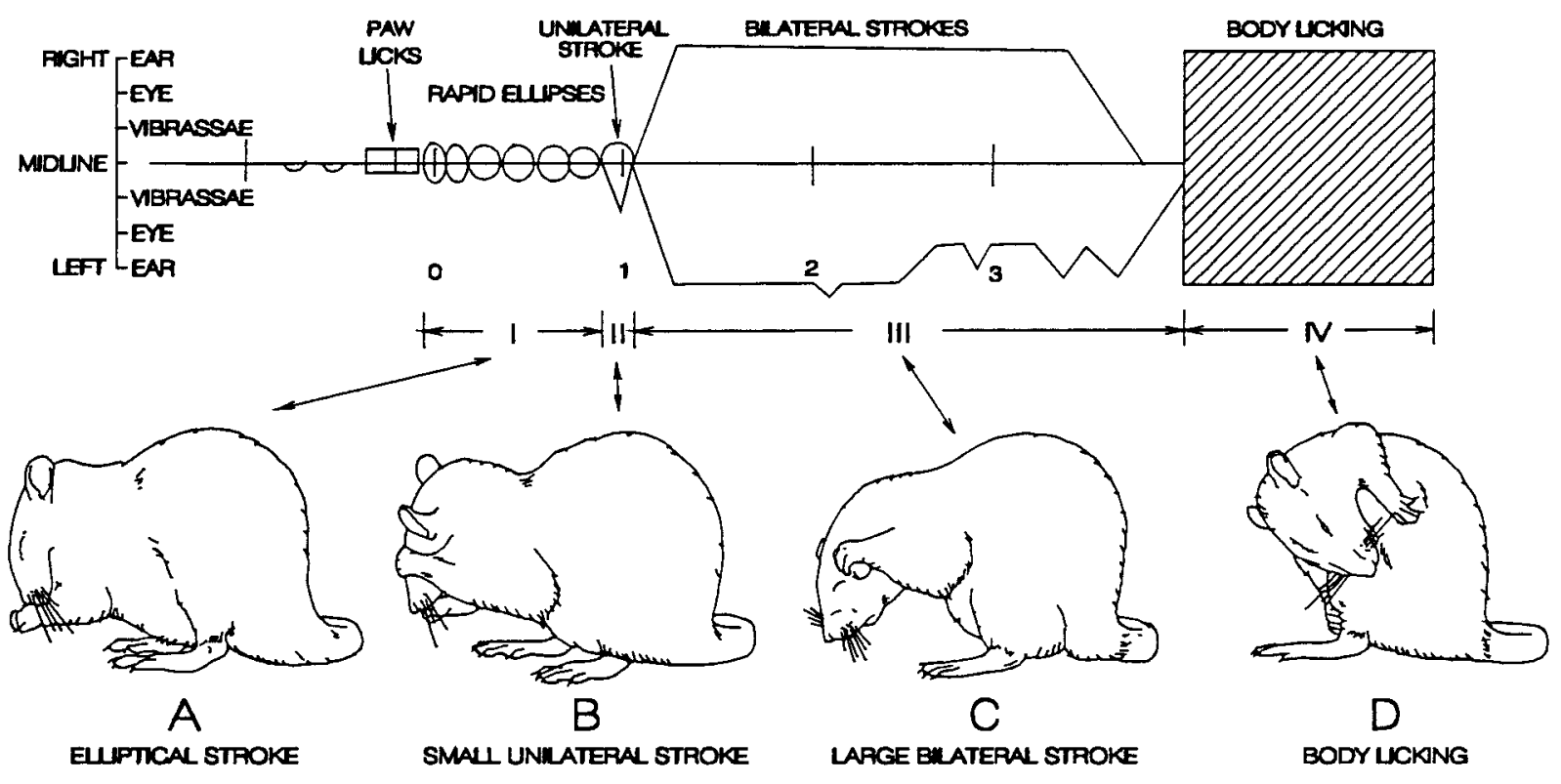

Fig. 1. Stereotyped grooming pattern. Choreograph of a syntactic grooming chain, which organizes movements into 4 phases, showing the moment-by-moment trajectories of forelimb strokes over the face and the occurrence of other grooming actions. Drawings below display the actions that typify each phase of syntactic chains. To read the choreographic transcription, time proceeds from left to right. The horizontal axis represents the position of the rat's nose, and stroke

ing. The strength of syntactic chain patterns can be measured in two different ways. (1) Initiation of syntactic chain patterns reflects the relative probability or tendency to begin the sequential pattern. The relative probability is calculated as the frequency of chain initiation per minute of time spent engaged in grooming. By calculating relative probability in this manner, we were able to correct for confounds produced by any changes in the overall amount of grooming. Without the correction syntactic chains might go up or down simply due to an increase or decrease in the amount of grooming behavior. (2) Completion of syntactic chain patterns reflects the pattern stereotypy, or relative probability of finishing the sequence once it is started. It is the best measure of stereotypy, whether the animals adhere to and fulfill the pattern of actions through all of the components of the sequence. It measures the proportion of chains that follow the predictable pattern to the completion end of the 4-phase sequence. Both initiation and completion measures of sequential pattern strength were used in this study.

\section{Subjects and doses}

Sprague-Dawley male rats ( $\mathrm{n}=10 ; 300-400 \mathrm{~g}$ ) were housed individually on a 14/10 hour light/dark cycle throughout the experiment. Grooming sequences were videotaped during 30-minute behavioral test sessions conducted on alternate days (between 2 and 6 p.m.). Five minutes prior to each test session, rats received peripheral injections (i.p.) of either the dopamine D1

trajectories over the face are depicted relative to the nose. Deviations of the lines above (right paw) and below (left paw) the horizontal axis represent the elevation (e.g., level of the eye, the ear, etc.) reached by each forepaw during a stroke. Small rectangles denote paw licks. Large rectangle denotes body licking (adapted from Aldridge et. al., 1990).

agonist, SKF 38393, or the dopamine D2 agonist, quinpirole, or ACTH-(1-24), or the control vehicle. Doses were chosen from the literature on excessive grooming and other behavior evoked by dopamine agonists (Cools et al., 1988; Hartgraves and Randall, 1986; Spruijt et al., 1986; Starr and Starr, 1986; Van Wimersma Greidanus et al., 1989), and from the literature on behavioral effects of peripheral ACTH administration (de Wied, 1990; Poggioli et al., 1986; Segarra et al., 1991; Vergoni et al., 1990): SKF $38393(0,10$, or $20 \mathrm{mg})$, quinpirole $(0,5.0$, or $10 \mathrm{mg} / \mathrm{kg})$, and ACTH-(1-24) (0, 2.0 , or $5.0 \mathrm{mg} / \mathrm{kg}$ ). Drugs were mixed fresh daily before each test. The order of drug and vehicle administration was balanced across rats. A separate vehicle trial was administered for each drug, but scores from these 3 trials never differed statistically from each other, so they were averaged into a single vehicle score for comparison to drugs in the statistical analyses below.

\section{Behavioral testing and video analysis}

Rats were habituated to the behavioral testing procedure for 4 consecutive days prior to the first drug administration. Each rat was placed into a chamber that had a transparent floor, below which an angled mirror reflected the image of the rat's ventral surface into the lens of a video camera.

Videotapes were later analyzed in slow motion (frame-by-frame to 1/10th actual speed depending on the density of movements) independently by 2 trained observers who were blind to the drug condition of the 
rats. Scores by different observers were compared and tapes were rescored when necessary to obtain consensus on each measure. We measured the total quantity of grooming, and two indices of the sequential pattern of grooming chains: the probability that the syntactic pattern would occur (initiation), and the stereotypy of the sequential pattern once it occurred (completion) (Berridge et al., 1987; Berridge and Whishaw, 1992; Colonnese et al., 1996; Cromwell and Berridge, 1996).

\section{Grooming quantity}

The quantity of all grooming (syntactic grooming chains and nonsyntactic or sequentially flexible grooming) was scored as the number of seconds that a rat spent engaged in grooming behavior, and was expressed as a percentage of the total observation session.

\section{Probability of pattern occurrence (chain initiation)}

A syntactic grooming chain pattern contains $15-25$ paw stroke and licking movements arranged into 4 consecutive phases (Berridge and Fentress, 1986). Initiation of a syntactic chain was considered to be the occurrence of Phase I followed immediately by Phase II or Phase III, as in earlier studies (Berridge and Whishaw, 1992; Cromwell and Berridge, 1996; Cromwell et al., 1998). Phase I: 5 to 9 small, rapid (at least 6 $\mathrm{Hz}$ ) forepaw strokes around the nose made by both paws simultaneously ("ellipses" because of their tight elliptical trajectories). Phase II: 1 to 4 small-to-medium strokes (up to the level of the eye) made by only one paw at a time (occasionally Phase II is omitted from a chain that is otherwise syntactically perfect). Phase III: 3 to 10 large strokes (past the ear) made simultaneously by both paws, often symmetrically with both paws. Phase IV: Rapid lateral turn of the head towards a flank followed immediately by body licking.

In order to assess the tendency to emit syntactic grooming chains, it was important to calculate the relative probability of pattern initiation (relative to grooming amount) rather than just the absolute number of syntactic patterns, since changes in the grooming amount would also change the number of patterns even if their relative probability remained unchanged (Berridge et al., 1987; Cromwell and Berridge, 1996). Therefore, the relative probability of chain initiation was calculated for each rat as the frequency of chain initiations per minute of time actually spent in grooming (chain initiation/grooming quantity).

\section{Pattern stereotypy (syntactic completion)}

Normal rats complete 80 to $90 \%$ of their syntactic chain patterns (Berridge, 1990; Berridge et al., 1987). Changes in this degree of stereotypy were assessed by calculating the proportion of chains that were com- pleted syntactically all the way to Phase IV. A completed pattern was considered to be a grooming sequence in which Phase I was followed immediately by subsequent phases leading to Phase IV. Phase IV had to occur to within 5 seconds of the last Phase I stroke in order for the chain to be considered syntactically complete. In addition, Phase I had to be followed consecutively by either Phase II, Phase III, and Phase IV in that order, or else by Phase III and Phase IV in that order (skipping only Phase II), without interruption by other movements (Berridge, 1989b; Berridge and Fentress, 1987b; Berridge and Whishaw, 1992; Cromwell and Berridge, 1996; Cromwell et al., 1998). The measure of pattern completion was calculated for each rat as the mean proportion of syntactic chains that, once begun, were completed to Phase IV following the above criteria (completed patterns/initiated patterns).

\section{Results \\ Grooming amount}

The amount of grooming was altered by drug administration $(\mathrm{F}(3,79)=15.2, P<0.001 ; 2$-way repeated measures ANOVA, factors were drug $\mathrm{X}$ dose, Fig. 2). The D1 agonist SKF 38393 increased the amount of grooming behavior. Grooming amount was approximately doubled after the D1 agonist (Fig. 2) compared to vehicle trials $(\mathrm{F}(1,39)=82.14, P<0.04)$. Both doses of SKF 38393 increased the proportion of time spent grooming compared to vehicle trials $(P<0.05)$, and to a similar degree. By contrast, administration of the D2 agonist, quinpirole $(\mathrm{F}(1,39)=103.3, P<0.001)$ decreased grooming to approximately $50 \%$ of control levels. Grooming was nearly abolished by peripheral administration of ACTH $(\mathrm{F}(1,39)=49.9,<\mathrm{P}<0.001)$.

\section{Initiation of syntactic chain sequences}

The relative probability that the sequential pattern would begin was altered by drug administration $(\mathrm{F}(3,79)=224.9, P<0.001$; Fig. 3$)$. The D1 agonist, SKF 38393, approximately tripled the relative probability that a syntactic chain would be initiated $(\mathrm{F}(1,39)$ $=208.3, P<0.001)$. This amounted to a nearly quadrupled level in the raw frequency of chain patterns (only half of which could be attributed to an overall increase in grooming; Fig. 2). Thus there was a specific increase in the tendency to begin the sequential pattern when D1 receptors were activated.

By contrast, administration of quinpirole dramatically reduced chain initiation per minute of grooming $(\mathrm{F}(1,39)=15.9, P<0.01)$. No change in chain initiation rates was observed after ACTH administration $(\mathrm{F}(1,39)=0.26)$. However, ACTH suppressed the quantity of grooming so powerfully (Fig. 2) that there was relatively little grooming behavior at all, making it difficult to statistically detect any possible change in initiation after this compound. 


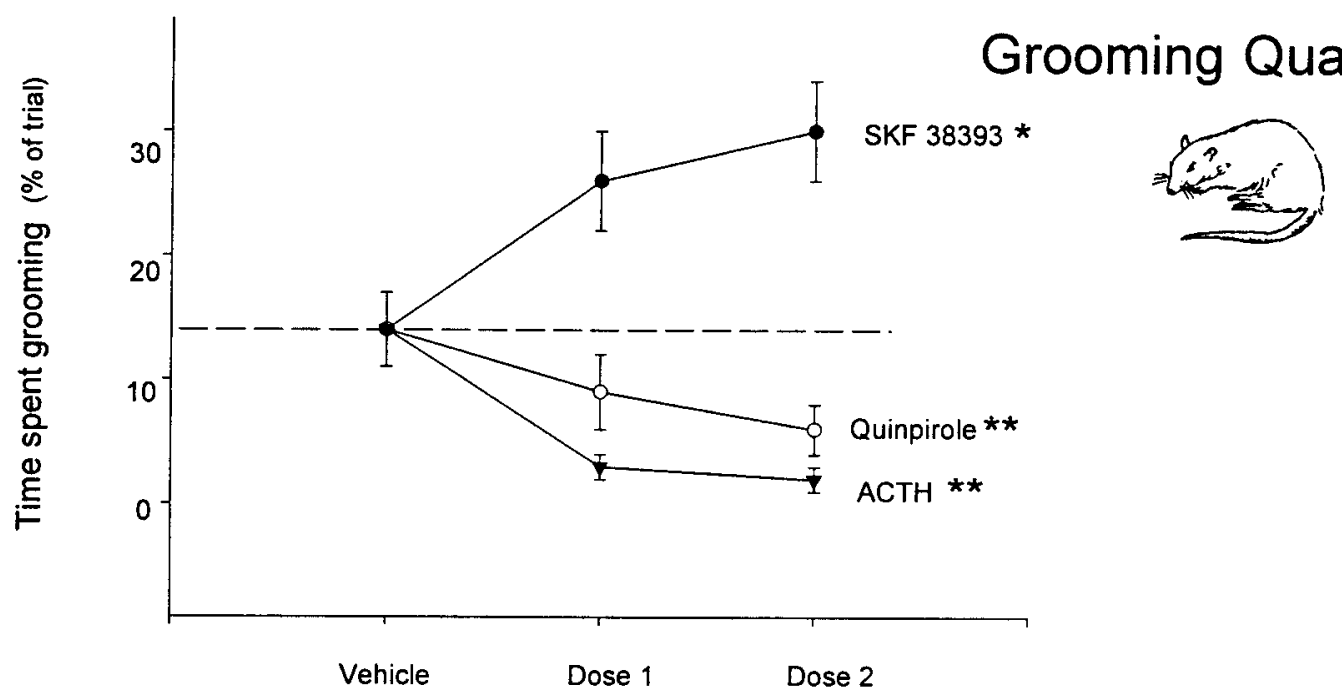

Fig. 2. Grooming amount (Experiment 1). Effects on time spent grooming of systemic SKF 38393, quinpirole, and ACTH. Amount of grooming is expressed as the percentage of time spent grooming out of the entire observation period (symbolized by rat engaged in grooming behavior). Dose 1: $\mathrm{SKF} 38393=10 \mathrm{mg} / \mathrm{kg}$., quinpirole $=5 \mathrm{mg} / \mathrm{kg}$, and

ACTH- $(1-24)=2 \mathrm{mg} / \mathrm{kg}$. Dose $2: \mathrm{SKF} 38393=20 \mathrm{mg} / \mathrm{kg}$, quinpirole $=$ $10 \mathrm{mg} / \mathrm{kg}$, and ACTH $=5 \mathrm{mg} / \mathrm{kg}$. An asterisk denotes a change from baseline level produced by a compound, statistically significant at $P<$ 0.05 . Two asterisks denote a change from baseline significance at $P<$ 0.01 .

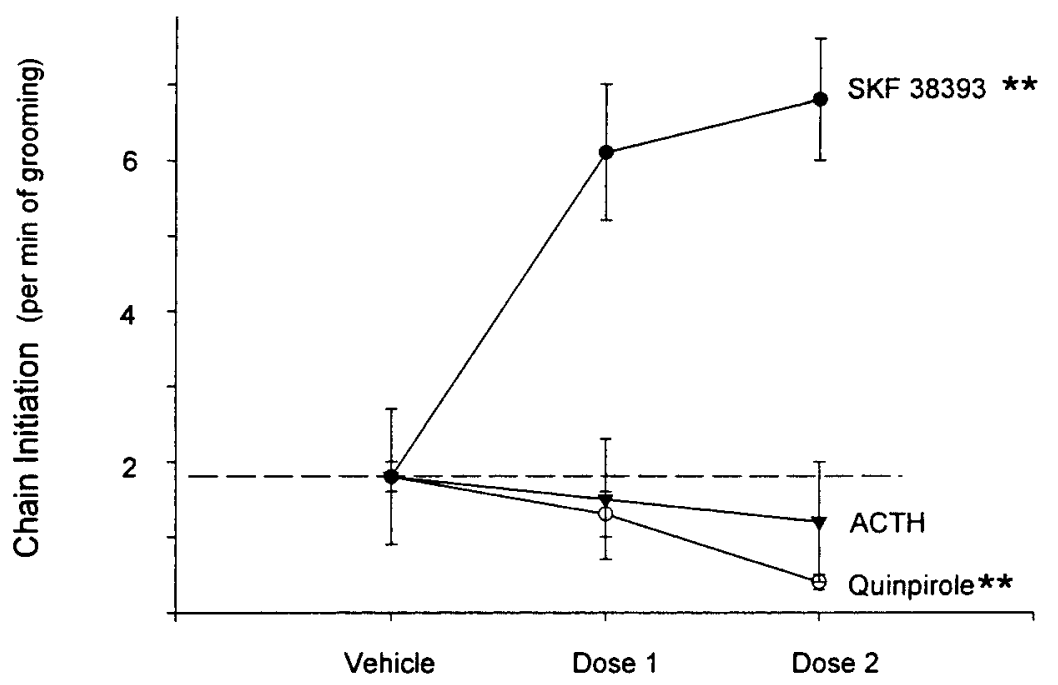

\section{Chain Initiation}

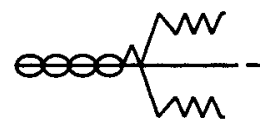

Fig. 3. Pattern probability: syntactic chain initiation (Experiment 1). Effects on the relative probability of beginning a stereotyped pattern of systemic SKF 38393, quinpirole, and ACTH. Relative probability is expressed as the rate of initiation of syntactic chains per minute of grooming behavior (symbolized by choreograph of first 3

\section{Pattern stereotypy: syntactic completion}

The proportion of grooming chains that completed the full stereotyped pattern through Phase IV, was altered by drug administration $(\mathrm{F} 3,79)=55.9, P<$ 0.01; Fig. 4). SKF 38393 appeared to produce a slight trend toward enhanced sequential stereotypy, but this enhancement effect was only marginally significant $(\mathrm{F}(1,39)=4.133, P=0.061)$. Rats completed approximately $90 \%$ of syntactic chains after vehicle control injections $(89 \pm 5 \%$, mean \pm SEM, proportion of chains phases of a syntactic grooming chain). Dose $1=\mathrm{SKF} 3839310 \mathrm{mg} / \mathrm{kg}$, quinpirole $5 \mathrm{mg} / \mathrm{kg}$, and ACTH-(1-24) $2 \mathrm{mg} / \mathrm{kg}$. Dose 2 = SKF 3839320 $\mathrm{mg} / \mathrm{kg}$, quinpirole $10 \mathrm{mg} / \mathrm{kg}$, and ACTH $5 \mathrm{mg} / \mathrm{kg}$. Statistical symbols as in Figure 2.

completed), and approximately $95 \%$ after receiving the D1 agonist $(10 \mathrm{mg} / \mathrm{kg}=96 \pm 6 \% ; 20 \mathrm{mg} / \mathrm{kg}=95 \pm 5 \%)$.

Again by contrast, quinpirole administration dramatically reduced stereotyped completion of the sequential pattern $(\mathrm{F}(1,39)=247, P<0.001)$. Completion was reduced to less than one-half of its normal level by both doses $(5 \mathrm{mg} / \mathrm{kg}=10 \pm 12 \% ; 10 \mathrm{mg} / \mathrm{kg}=$ $13 \pm 8 \%$ ). Syntactic completion was also reduced by ACTH at both doses (Fig. 4; though the small size of the grooming sample after ACTH administration makes it 
difficult to assign weight; $\mathrm{F}(1,39)=224.3, P<0.001 ; 2$ $\mathrm{mg} / \mathrm{kg}=15 \pm 13 \% ; 5 \mathrm{mg} / \mathrm{kg}=51 \pm 10 \%)$.

\section{Discussion of experiment 1}

Our results concerning the amount of grooming after drugs are consistent with those of earlier studies: only the D1 agonist SKF 38393 enhanced grooming behavior. Both the D2 agonist, quinpirole, and ACTH consistently suppressed the amount of grooming behavior at the doses tested.

What is new here is the effect of these agents on the stereotyped grooming pattern. Administration of the D1 agonist SKF 38393 increased the relative probability of emission for syntactic chains, in addition to increasing overall grooming quantity. The increase in the emission of syntactic grooming sequences comes at the expense of less patterned grooming. The tendency to initiate syntactic chain patterns of grooming (over $300 \%$ of control levels) was increased after SKF 38393 more than was the mere amount of grooming (only $200 \%$ of control levels). Quinpirole and ACTH each failed to facilitate chain initiation. Thus, D1 receptors may play a special role in the disposition to engage in this complex sequential pattern.

Whether D1 receptors also facilitated the stereotyped completion of the sequential patterns, once they were initiated, was not quite as clear. There did appear to be a slight trend toward an enhancement of pattern completion after SKF 38393, from the normal 90 to $95 \%$, but this effect only reached a marginal significance level of $P=$ 0.06 . It is possible that a statistical ceiling effect obscures drug-induced enhancement of completion, since rats normally complete up to 9 out of 10 syntactic chains they begin. Conversely, completion of the grooming pattern was reduced by quinpirole and ACTH.

The possibility that $\mathrm{D} 1$ activation might produce superstereotypy of the complex grooming sequence appeared to need further examination, given the statistically marginal enhancement noted above. Therefore, Experiment 2 repeated the procedures, using two different D1 agonists, SKF 38393 and SKF 82958, and an expanded range of doses. SKF 82958 was added for comparison because it is a full D1 agonist, whereas SKF 38393 is a partial D1 agonist (i.e., it achieves less adenylate cyclase activity than dopamine itself) (Mottola et al., 1996). SKF 82958 has also been suggested to activate D2 autoreceptors (Ruskin et al., 1998). Although simple assumptions regarding the consequences of full vs. partial agonists cannot be made (Watts et al., 1995), it seemed possible that a full agonist might be more effective at increasing the strength of the behavioral pattern.

\section{EXPERIMENT 2 Methods \\ Subjects and compounds}

Naive Sprague-Dawley male rats $(\mathrm{n}=12 ; 300-400$ g) were tested using procedures similar to Experiment
1. The two dopamine D1 agonists, SKF 38393 and SKF 82958, were tested at four doses each plus vehicle (SKF $38393=0$ [vehicle], and 2.5, 5.0, 10, and $20 \mathrm{mg} / \mathrm{kg} ; \mathrm{SKF}$ $82958=0$ [vehicle], and $0.1,0.2,0.5$, and $1.0 \mathrm{mg} / \mathrm{kg}$; i.p.). For analysis purposes, the two vehicle doses were combined for each rat to create a single vehicle score. The averaged vehicle score was compared to drug dose scores by repeated measures ANOVA. Trials were spaced 48 hours apart, and the order of drug and dose administration was counterbalanced.

\section{Grooming amount \\ Results}

The amount of time spent grooming was changed by D1 agonist administration $(\mathrm{F}(1,117)=30.48, P<$ 0.001 ), but the full vs. partial D1 agonists differed in their effects $(\mathrm{F}(4,114)=2.8, P<0.05)$. Grooming amount was increased only by the partial D1 agonist, SKF 38393 (Fig. 5). Although an initial evaluation of SKF 38393 effects using all 4 doses and vehicle was not significant (ANOVA, $\mathrm{F}(4,59)=1.93, P=0.12$ ), the grooming increase was significant when the analysis was restricted to the doses used in Experiment 1 (the two highest doses used in Experiment 2 plus vehicle) $(\mathrm{F}(2,35)=5.41, P<0.01)$. Post hoc tests further showed that each of the highest two doses of SKF 38393 elicited more grooming than vehicle (Bonferroni paired test, $p<0.05$ each). Finally, an ANOVA of grooming bout duration using all doses showed that grooming bouts tended to be longer after SKF 38393 administration $(\mathrm{F}(4,59)=8.12, \mathrm{p}<0.01$; vehicle mean duration $=24 \pm 5$ seconds, mean \pm SEM; SKF 38393 $2.5 \mathrm{mg} / \mathrm{kg}=27 \pm 3$ seconds; $5 \mathrm{mg} / \mathrm{kg}=30 \pm 6$ seconds; $10 \mathrm{mg} / \mathrm{kg}=36 \pm 8$ seconds $20 \mathrm{mg}=34 \pm 6$ seconds).

The full D1 agonist SKF 82958 did not increase the quantity of grooming at any dose $($ F94,54 $)=2.01, P=$ 0.11, Fig. 5). In fact, when the highest dose was excluded, there was a significant suppression of grooming amount across the three lower doses of the full D1 agonist $(\mathrm{F}(3,47)=3.13, P<0.05)$. Post-hoc tests indicated that grooming after the $5 \mathrm{mg} / \mathrm{kg}$ dose of SKF 82958 was significantly lower than baseline (Bonferroni test, $P<0.05$ ). Further, the average duration of a grooming bout decreased after each dose of SKF 82958 compared to vehicle $(\mathrm{F}(4,59)=18.41, P<0.01$; vehicle $=24.5 \pm 5$ seconds; SKF $829580.1 \mathrm{mg} / \mathrm{kg} 23.2 \pm 6$ seconds; $0.2 \mathrm{mg} / \mathrm{kg}=16 \pm 4$ seconds; $0.5 \mathrm{mg} / \mathrm{kg}$ $=11.3 \pm 2$ seconds; $1.0=13 \pm 5$ seconds).

\section{Initiation of syntactic chain sequences}

The relative probability of beginning a stereotyped sequential pattern was increased by both the SKF 82958 and SKF $38393(\mathrm{~F} 4,114)=11.24, P<0.001$; Fig. $6)$. The full D1 agonist SKF 82958 enhanced the initiation of syntactic chains to levels nearly 5 times baseline $(\mathrm{F}(4,59)=6.28, P<0.001)$. This SKF 82958 in- 


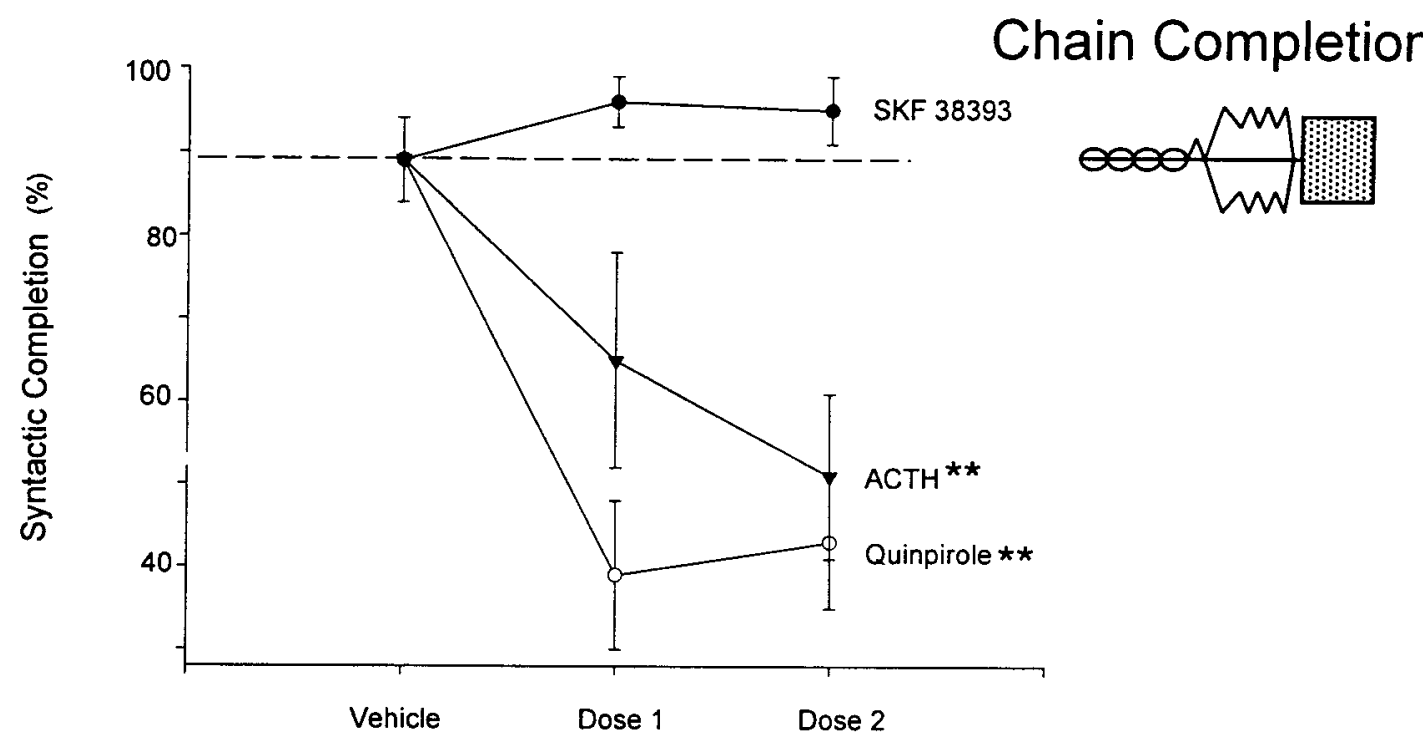

Fig. 4. Pattern stereotypy: syntactic chain completion (Experiment 1). Effects on the completion of syntactic chain patterns of systemic SKF 38393, quinpirole, and ACTH. Syntactic completion is expressed as the percentage of grooming chains that were fully completed through Phase IV, as a proportion of those that were begun

(symbolized by choreograph of completed syntactic grooming chain). Dose 1 = SKF $3839310 \mathrm{mg} / \mathrm{kg}$, quinpirole $5 \mathrm{mg} / \mathrm{kg}$, and ACTH-(1-24) $2 \mathrm{mg} / \mathrm{kg}$. Dose 2 = SKF $3839320 \mathrm{mg} / \mathrm{kg}$, quinpirole $10 \mathrm{mg} / \mathrm{kg}$, and ACTH $5 \mathrm{mg} / \mathrm{kg}$. Statistical symbols as in Figure 2.

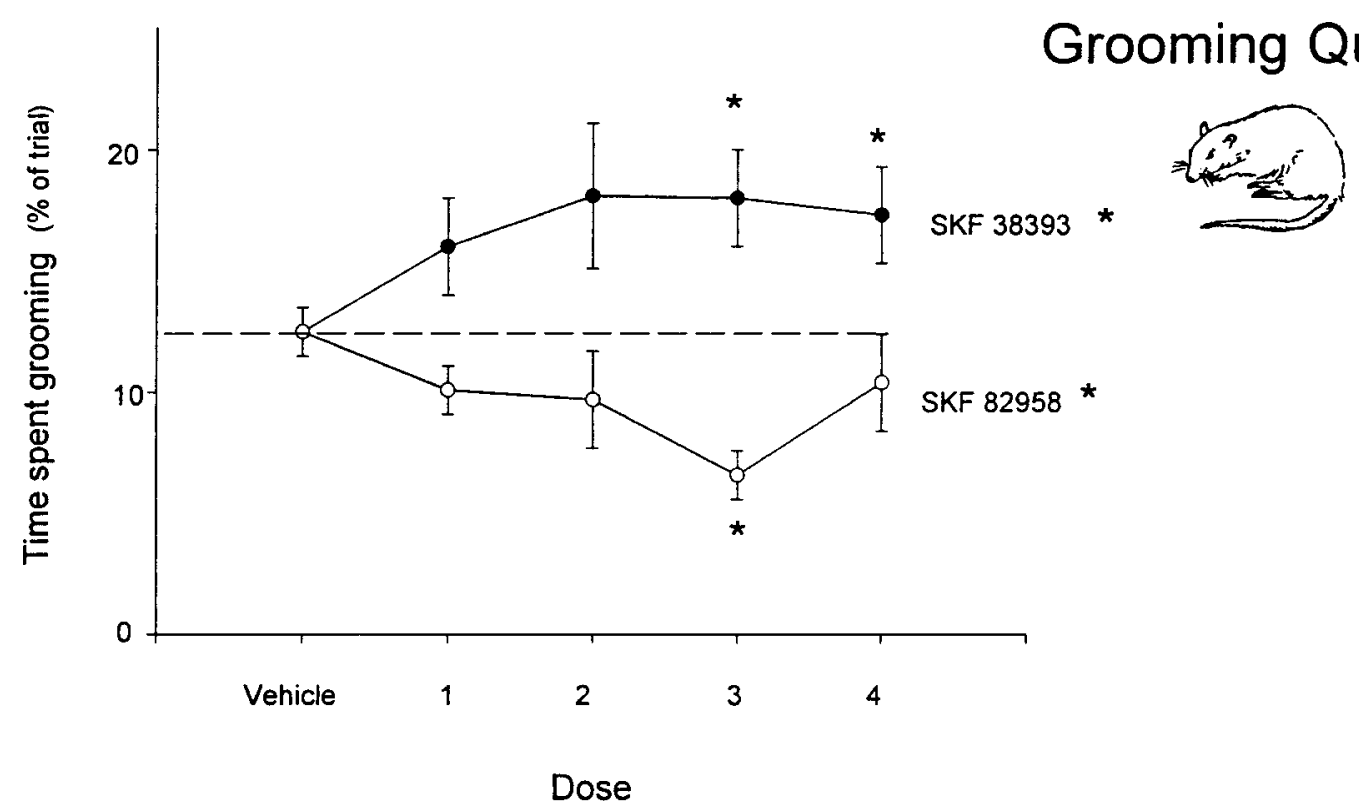

Fig. 5. Grooming amount (Experiment 2). Effects on time spent grooming of systemic SKF 38393, quinpirole, and ACTH. Amount of grooming is expressed as the percentage of time spent grooming out of the entire observation period (symbolized by rat engaged in grooming behavior). Dose 1: SKF $38393=2.5 \mathrm{mg} / \mathrm{kg}$; SKF $82958=0.1 \mathrm{mg} / \mathrm{kg}$.

crease in chain initiation was higher than the increase produced by the partial agonist, $\mathrm{SKF} 38393(\mathrm{~F}(1,117)=$ $36.72, P<0.001)$. The relative probability of engaging in the sequential pattern was elevated over vehicle baseline (per minute of grooming) after the $0.2,0.5$, and 1.0 doses of SKF 82958 ( $P<0.05$ each, Bonferroni). Further, the frequency of chain initiation per minute of
Dose 2: SKF $38393=5.0 \mathrm{mg} / \mathrm{kg}$; SKF $82958=0.2 \mathrm{mg} / \mathrm{kg}$. Dose 3: SKF $38393=10 \mathrm{mg} / \mathrm{kg}$; SKF $82958=0.5 \mathrm{mg} / \mathrm{kg}$. Dose 4: SKF $38393=20$ $\mathrm{mg} / \mathrm{kg}$; SKF $82958=1.0 \mathrm{mg} / \mathrm{kg}$. Statistical symbols as in Figure 2. Symbols at particular doses indicate significance levels in individual comparisons.

grooming was higher after each of the 3 largest doses of the full D1 agonist than after any dose of the partial D1 agonist $(P<0.05$ each, Bonferroni).

The partial D1 agonist roughly doubled the initiation of the sequential pattern over baseline $(\mathrm{F}(4,59)=$ $10.06, P<0.001)$. In individual comparisons the tendency to engage in the sequence was elevated over 


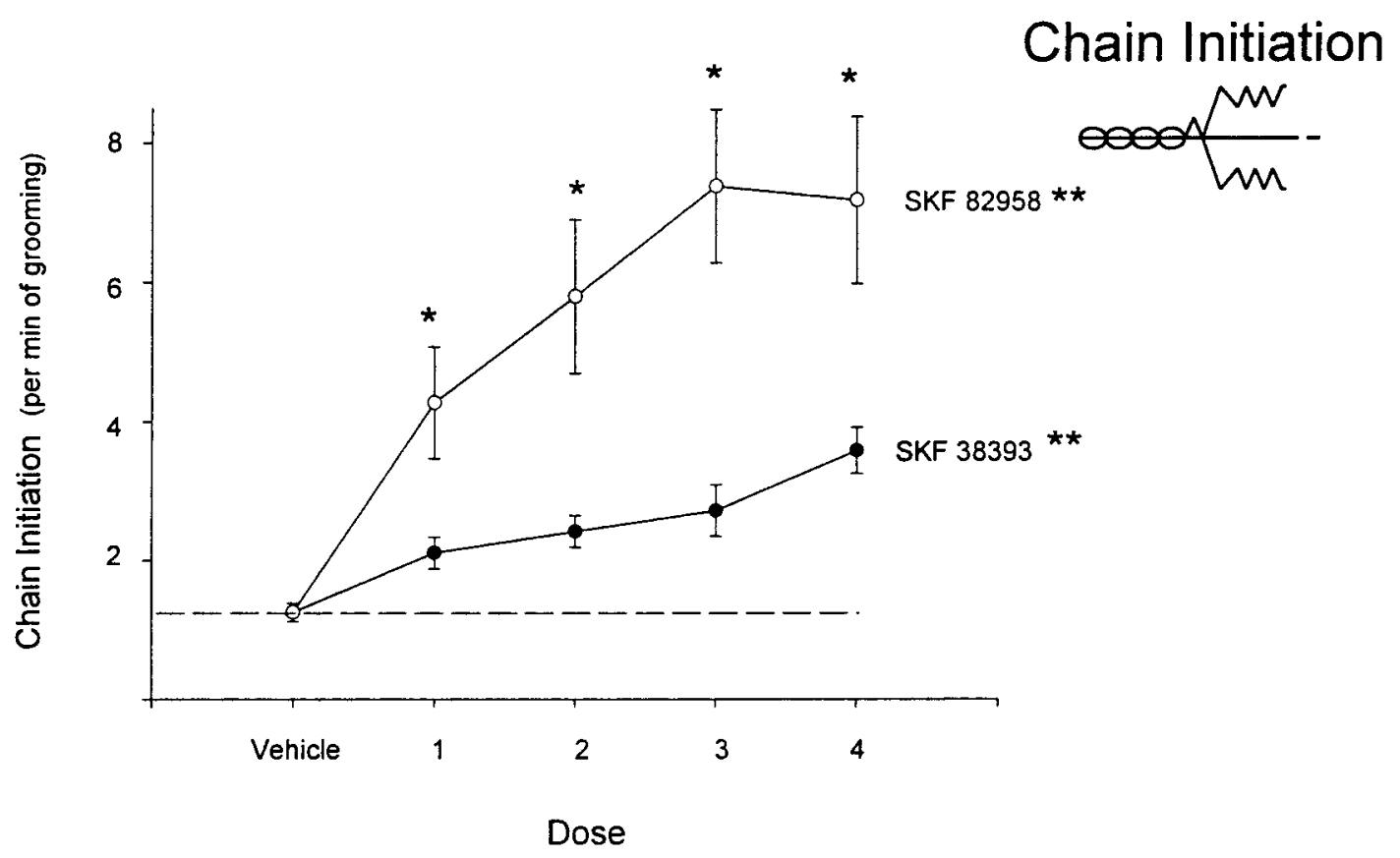

Fig. 6. Pattern probability: syntactic chain initiation (Experiment 2). Effects on the relative probability of beginning a stereotyped pattern of systemic SKF 38393, quinpirole, and ACTH. Relative probability is expressed as the rate of initiation of syntactic chains per minute of grooming behavior (symbolized by choreograph of first 3 phases of a syntactic grooming chain). Dose 1 : SKF $38393=2.5$

baseline at each of the 5,10 , and $20 \mathrm{mg} / \mathrm{kg}$ doses $(P<$ 0.05 each comparison, Bonferroni). The frequency at which chain sequences were initiated after $20 \mathrm{mg} / \mathrm{kg}$ was also significantly elevated over the 2.5 and the 5 $\mathrm{mg} / \mathrm{kg}$ dose $(P<0.05$ each $)$.

\section{Pattern stereotypy: syntactic completion}

The proportion of patterns that were fully stereotyped, in the sense of being completed syntactically from Phase I through Phase IV, was changed by both D1 agonists, but not in the same way $(\mathrm{F}(1,117)=19.36$, $P<0.001$; Fig. 7). Rats completed $84 \pm 3 \%$ after vehicle administration (slightly lower than the baseline in Experiment 1). In this experiment, the partial agonist, SKF 38393, significantly increased pattern completion by nearly $10 \%$, so that over 9 out of 10 chains were fully completed $(92 \% \pm 4 \% ; \mathrm{F}(4,59)=3.32, P<0.05)$. Every dose tested of SKF 38393 increased the probability of particular dose of the partial D1 agonist elevated the completion proportion over the vehicle control level $(P<0.05$ each, Dunnett's paired test).

The full agonist, SKF 82958, did not enhance pattern completion at any dose tested. In fact, there appeared to be a trend toward suppression of syntactic completion (Fig. 7). However, variance was high and the suppressive trend did not reach significance $(\mathrm{F}(4,59)=$ 0.96 , n.s.). $\mathrm{mg} / \mathrm{kg}$; SKF $82958=0.1 \mathrm{mg} / \mathrm{kg}$. Dose 2: SKF $38393=5.0 \mathrm{mg} / \mathrm{kg} ; \mathrm{SKF}$ $82958=0.2 \mathrm{mg} / \mathrm{kg}$. Dose 3: SKF $38393=10 \mathrm{mg} / \mathrm{kg} ; \mathrm{SKF} 82958=0.5$ $\mathrm{mg} / \mathrm{kg}$. Dose 4: SKF $38393=20 \mathrm{mg} / \mathrm{kg}$; SKF $82958=1.0 \mathrm{mg} / \mathrm{kg}$. Symbols at particular doses indicate significance in individual dose vs. baseline comparisons. Statistical symbols as in Figure 2 .

\section{GENERAL DISCUSSION}

These results indicate that dopamine D1 agonists can increase the emission of complex and sequentially stereotyped patterns of actions. Peripheral administration of a D1 agonist (but not of a D2 agonist or of ACTH) enhanced the sequential pattern of "syntactic chains." This is the first demonstration of an enhancement of the syntactic grooming chain pattern, and stands in contrast to a variety of dopamine or neostriatum-related brain lesions that impair the patterned sequence (Berridge, 1989a,b; Berridge and Fentress, 1987b; Berridge and Whishaw, 1992; Cromwell and Berridge, 1996).

"Super-stereotypy" of the syntactic grooming pattern was produced in two ways by D1 agonists. First, rats increased their tendency to engage in the sequential pattern. The relative probability of initiating a syntactic chain was increased by the partial D1 agonist SKF 38393 and the full D1 agonist SKF 82958. This increase in the tendency to emit the stereotyped pattern came at the relative expense of less stereotyped sequences of grooming.

Second, SKF 38393 also enhanced adherence to the syntactic pattern by increasing the likelihood of completing the entire chain syntactically. The ordinary probability that a rat will complete a syntactic chain once it starts is 80 to $90 \%$ (Aldridge and Berridge, 1998; Aldridge et al., 1993; Berridge, 1990; Berridge and 


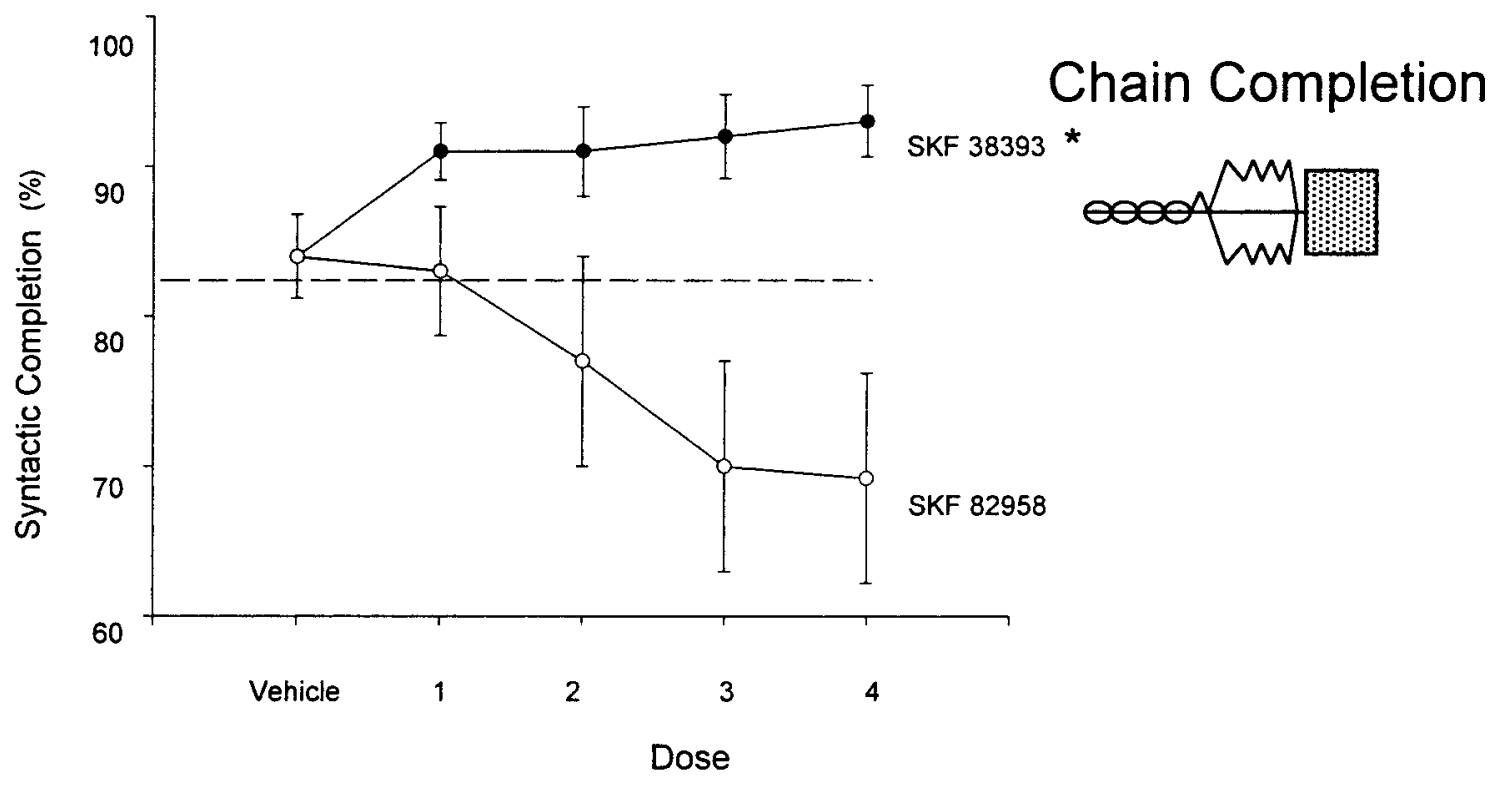

Fig. 7. Pattern stereotypy: Syntactic Chain Completion (Experiment 2). Effects on the completion of syntactic chain patterns of systemic SKF 38393, quinpirole, and ACTH. Syntactic completion is expressed as the percentage of grooming chains that were fully completed through Phase IV, as a proportion of those that were begun

Fentress, 1986; Berridge et al., 1987; Colonnese et al., 1996). This normally high rate of pattern fulfillment makes it difficult to detect further enhancement, since completion cannot rise above $100 \%$. That ceiling effect may have obscured the enhancement of syntactic completion in Experiment 1, where the rise reached only marginal significance. However, the enhancement of completion was fully significant in Experiment 2, with completion rising from roughly $85 \%$ to up to $96 \%$ after administration of SKF 38393.

Grooming sequences therefore became sequentially super-stereotyped after administration of the partial D1 agonist. A special role for D1 receptors in the completion of this stereotyped pattern is consistent with the finding that mutant mice, which lack dopamine D1-A receptors, have sequential deficits in the completion of the pattern (Cromwell et al., 1998). The ability of dopamine activation to cause sequences to become superstereotyped is also consistent with the observation by Aldridge and colleagues that neostriatal neurons code the sequential pattern of syntactic chains (Aldridge and Berridge, 1998; Aldridge et al., 1993), suggesting that D1 agonists may potentiate neuronal coding of the sequence in the neostriatum.

\section{Comparing the effects of compounds tested:} SKF 38393, SKF 82958, quinpirole, ACTH

Although D2 dopamine agonists are reported to be most efficacious at evoking simple repetitive movement stereotypies (Cooper and Dourish, 1990; Delfs and Kelley, 1990; Sullivan et al., 1992; White et al., 1988), only the D1 dopamine agonists, SKF 38393 and SKF (symbolized by choreograph of completed syntactic grooming chain). Dose 1: SKF $38393=2.5 \mathrm{mg} / \mathrm{kg}$; SKF $82958=0.1 \mathrm{mg} / \mathrm{kg}$. Dose 2: SKF $38393=5.0 \mathrm{mg} / \mathrm{kg} ; \mathrm{SKF} 82958=0.2 \mathrm{mg} / \mathrm{kg}$. Dose 3: SKF $38393=10$ $\mathrm{mg} / \mathrm{kg}$; SKF $82958=0.5 \mathrm{mg} / \mathrm{kg}$. Dose 4: SKF $38393=20 \mathrm{mg} / \mathrm{kg}$; SKF $82958=1.0 \mathrm{mg} / \mathrm{kg}$. Statistical symbols as in Figure 2 .

82958 , increased the sequential stereotypy of the complex pattern of syntactic grooming chains. Neither the dopamine D2 agonist, quinpirole, nor the peptide, ACTH-(1-24) produced any tendency for super-stereotypy. Both quinpirole and ACTH suppressed the total amount of grooming, consistent with results from other studies (McDougall et al., 1993; Van Wimersma Greidanus et al., 1989), and both also suppressed the likelihood that the sequential pattern would be completed when it occurred. Quinpirole, in addition, suppressed initiation of the stereotyped pattern. This may indicate that simple and complex forms of stereotypy have fundamentally different mechanisms. Although the simple repetition of movements may be facilitated by $\mathrm{D} 2$ agonists, the stereotypy of more complex movement patterns may depend more on D1 activation.

\section{Dissociation of grooming amount vs. grooming stereotypy}

Earlier lesion and gene-mutation studies found that the amount of grooming is often controlled separately from the pattern sequential stereotypy of syntactic chains (Berridge, 1989b; Berridge and Fentress, 1987b; Bolivaar et al., 1996; Coscia and Fentress, 1993; Cromwell and Berridge, 1996). Our study provides further evidence for a dissociation between the amount of grooming and its sequential pattern. Both the frequency and completion levels were generally suppressed by the D2 agonist, quinpirole, and by ACTH. Both D1 agonists (SKF 38393 and SKF 82958) resulted in more sequence initiation, but only SKF 38393 increased the frequency of complex grooming sequences. 
SKF 82958 at some doses actually reduced grooming amount, even while enhancing the relative probability of syntactic patterns. However, it remains for other studies to reveal whether it is possible to increase overall grooming amount without also increasing the relative probability of syntactic chain patterns (Berridge and Aldridge, pages $000-000$, this issue).

Finally, there was a dissociation regarding the facilitation of the pattern's initiation (relative probability of occurrence) vs. facilitation of its completion. SKF 82958 strongly facilitated pattern initiation, but actually suppressed completion. This supports earlier reports that it is possible to change pattern completion independently of initiation (Berridge and Whishaw, 1992; Cromwell and Berridge, 1996; Cromwell et al., 1998).

\section{Conclusion}

Our results indicate that sequential super-stereotypy can occur after D1 receptor activation. Dopamine D1 receptors appear to play a special role in the stereotypy of complex movement sequences, since only D1 agonists and not D2 agonists enhance the relative probability of the syntactic pattern and adherence to the pattern during the flow of behavior, and a D1 agonist promoted the relative emission of stereotyped sequences even when it did not increase the overall amount of grooming behavior.

\section{ACKNOWLEDGMENTS}

This work was supported by grants from the National Science Foundation (IBN 9604408 to KCB) and National Institutes of Health (NS31650 to JWA). We are grateful for assistance with the experiment and behavioral scoring to Gretchen Arnold, Paresh Patel, and Jarrod Montague.

\section{REFERENCES}

Adani N, Kiryati N, Golani I. 1991. The description of rat druginduced behavior: Kinematics versus response categories. Neurosci Biobehav Rev 15:455-460.

Aldridge JW, Berridge KC. 1998. Coding of serial order by neostriatal neurons: A "natural action" approach to movement sequence. J Neurosci 18:2777-2787.

Aldridge JW, Berridge KC, Herman M, Zimmer L. 1993. Neuronal coding of serial order: Syntax of grooming in the neostriatum. Psychol Sci 4:391-395.

Attneave F. 1959. Applications of information theory to psychology. Chicago: Holt, Rinehart, and Winston.

Berridge KC. 1989a. Progressive degradation of serial grooming chains by descending decerebration. Behav Brain Res 33:241-253. Berridge KC. 1989b. Substantia nigra 6-OHDA lesions mimic striatopallidal disruption of syntactic grooming chains: a neural systems analysis of sequence control. Psychobiology 17:377-385.

Berridge KC. 1990. Comparative fine structure of action: Rules of form and sequence in the grooming patterns of six rodent species. Behavior 113:21-56.

Berridge KC, Aldridge JW. 2000. Super-stereotypy II: Enhancement of a complex movement sequence by intraventricular dopamine D1 agonists. Synapse 37:205-215.

Berridge KC, Fentress JC. 1986. Contextual control of trigeminal sensorimotor function. J Neurosci 6:325-330.

Berridge KC, Fentress JC. 1987a. Deafferentation does not disrupt natural rules of action syntax. Behav Brain Res 23:69-76.
Berridge KC, Fentress JC. 1987b. Disruption of natural grooming chains after striatopallidal lesions. Psychobiol 15:336-342.

Berridge KC, Whishaw IQ. 1992. Cortex, striatum and cerebellum: Control of serial order in a grooming sequence. Exp Brain Research 90:275-290.

Berridge KC, Fentress JC, Parr H. 1987. Natural syntax rules control action sequence of rats. Behav Brain Res 23:59-68.

Bolivar VJ, Danilchuk W, Fentress JC. 1996. Separation of activation and pattern in grooming development of weaver mice. Behav Brain Res 75:49-58.

Bolles RC, Woods PJ. 1964. The ontogeny of behaviour in the albino rat. Animal Behaviour 12:427-441.

Bressers WM, Kruk MR, Van Erp AM, Willekens-Bramer DC, Haccou P, Meelis E. 1995. Time structure of self-grooming in the rat: Self-facilitation and effects of hypothalamic stimulation and neuropeptides. Behav Neurosci 109:955-964.

Colonnese MT, Stallman EL, KC B. 1996. Ontogeny of action syntax in altricial and precocial rodents: Grooming sequences by rat and guinea pig pups. Behavior 133:1165-1195.

Cools AR, Scheenen W, Eilam D, Golani I. 1989. Evidence that apomorphine and (+)-amphetamine produce different types of circling in rats. Behav Brain Res 34:111-116.

Cools AR, Spruijt BM, Ellenbroek BA. 1988. Role of central dopamine in ACTH-induced grooming behavior in rats. Ann NY Acad Sci 525:338-349.

Cools AR, Wiegant VM, Gispen WH. 1978. Distinct dopaminergic systems in ACTH-induced grooming. Eur J Pharmacol 50:265-268.

Cooper SJ, Dourish CT. 1990. Neurobiology of stereotyped behaviour. Oxford, U.K.: Oxford University Press.

Coscia EM, Fentress JC. 1993. Neurological dysfunction expressed in the grooming behavior of developing Weaver mutant mice. Behav Genet 23:533-541.

Cromwell HC, Berridge KC. 1996. Implementation of action sequences by a neostriatal site: A lesion mapping study of grooming syntax. J Neurosci 16:3444-3458.

Cromwell HC, Berridge KC, Drago J, Levine MS. 1998. Action sequencing is impaired in D1A-deficient mutant mice. Euro J Neurosci 10:2426-2432.

de Wied D. 1990. Neurotrophic effects of ACTH/MSH neuropeptides. Acta Neurobiologiae Experimentalis 50:353-366.

Delfs JM, Kelley AE. 1990. The role of D1 and D2 dopamine receptors in oral stereotypy induced by dopaminergic stimulation of the ventrolateral striatum. Neuroscience 39:59-67.

Deveney AM, Waddington JL. 1995. Pharmacological characterization of behavioural responses to SK\&F 83959 in relation to 'D1-like' dopamine receptors not linked to adenylyl cyclase. Br J Pharmacol 116:2120-2126.

Deveney AM, Waddington JL. 1997. Psychopharmacological distinction between novel full-efficacy "D-1-like" dopamine receptor agonists. Pharmacol Biochem Behav 58:551-558.

Dickson PR, Lang CG, Hinton SC, Kelley AE. 1994. Oral stereotypy induced by amphetamine microinjection into striatum: An anatomical mapping study. Neuroscience 61:81-91.

Downes RP, Waddington JL. 1993. Grooming and vacuous chewing induced by SK\&F 83959, an agonist of dopamine 'D1-like' receptors that inhibits dopamine-sensitive adenylyl cyclase. Eur J Pharmacol 234:135-136

Drago J, Gerfen CR, Lachowicz JE, Steiner H, Hollon TR, Love PE, Ooi GT, Grinberg A, Lee EJ, Huang SP. 1994. Altered striatal function in a mutant mouse lacking D1A dopamine receptors. Proc Natl Acad Sci USA 91:12564-12568.

Dunn AJ. 1988. Studies on the neurochemical mechanisms and significance of ACTH-induced grooming. Ann NY Acad Sci 525:150168 .

Dunn AJ, Berridge CW. 1990. Physiological and behavioral-responses to corticotropin-releasing factor administration-Is CRF a mediator of anxiety or stress responses. Brain Res Rev 15:71-100.

Dunn AJ, Alpert JE, Iversen SD. 1984. Dopamine denervation of frontal cortex or nucleus accumbens does not affect ACTH-induced grooming behaviour. Behav Brain Res 12:307-315.

Dunn AJ, Berridge CW, Lai YI, Yachabach TL. 1987. CRF-induced excessive grooming behavior in rats and mice. Peptides 8:841-844.

Eilam D, Golani I. 1990. Home base behavior in amphetamine-treated tame wild rats (Rattus norvegicus). Behav Brain Res 36:161-170.

Eilam D, Golani I, Szechtman H. 1989. D2-agonist quinpirole induces perseveration of routes and hyperactivity but no perseveration of movements. Brain Res 490:255-267.

Eilam D, Talangbayan H, Canaran G, Szechtman H. 1992. Dopaminergic control of locomotion, mouthing, snout contact, and grooming: opposing roles of D1 and D2 receptors. Psychopharmacology 106:447-454. 
Fentress JC. 1968. Interrupted ongoing behaviour in two species of vole (Microtus agrestis and Clethrionomys britannicus). I. Response as a function of preceding activity and the context of an apparently "irrelevant" motor pattern. Anim Behav 16:135-153.

Fentress JC. 1972. Development and patterning of movement sequences in inbred mice. In J. Kiger (Ed.). The Biology of Behavior. Corvallis: Oregon State University Press. pp. 83-132.

Fentress JC. 1973. Development of grooming in mice with amputated forelimbs. Science 179:704-705.

Fentress JC. 1977. The tonic hypothesis and the patterning of behavior. Ann NY Acad Sci 290:370-395.

Fentress JC, Stilwell FP. 1973. Letter: grammar of a movement sequence in inbred mice. Nature 244:52-53.

Gispen WH, Wiegant VM, Greven HM, de Wied D. 1975. The induction of excessive grooming in the rat by intraventricular application of peptides derived from ACTH: structure-activity studies. Life Sci 17:645-652.

Guild AL, Dunn AJ. 1982. Dopamine involvement in ACTH-induced grooming behavior. Pharmacol Biochem Behav 17:31-36.

Hartgraves SL, Randall PK. 1986. Dopamine agonist-induced stereotypic grooming and self-mutilation following striatal dopamine depletion. Psychopharmacology 90:358-363.

Isaacson RL, Thomas J. 1986. Character of (D-Phe-7) ACTH4-10induced excessive grooming. Exp Neurol 93:657-661.

Isaacson RL, Hannigan JH Jr, Brakkee JH, Gispen WH. 1983. The time course of excessive grooming after neuropeptide administration. Brain Research Bull 11:289-293.

Kulkosky PJ, Foderaro MA, Glazner GW, Niichel VI, Schnur P. 1988. Bombesin-induced grooming in the golden hamster. Behav Brain Res 29:173-177.

Lawrence AB, Rushen J. 1993. Stereotypic animal behaviour: fundamentals and applications to welfare. Tucson, AZ: CAB International.

Marin C, Chase TN. 1995. Effects of Sch-32615, an enkephalinase inhibitor, on D-1 and D-2 dopamine receptor-mediated behaviors. Neuropharmacology 34:677-682.

Marin C, Engber TM, Chaudhuri P, Peppe A, Chase TN. 1996. Effects of kappa receptor agonists on D1 and D2 dopamine agonist and antagonist-induced behaviors. Psychopharmacology 123:215-221.

McDougall SA, Crawford CA, Nonneman AJ. 1993. Behavioral effects of selective and nonselective dopamine agonists on young rats after irreversible antagonism of D1 and/or D2 receptors. Psychopharmacology 111:225-232

McKenzie JS, Everett PW, Kunze WA. 1984. Multiunit bursts in rat pallidum during grooming and stereotyped jaw movements. Brain Res Bull 13:493-496.

Molloy AG, Waddington JL. 1984. Dopaminergic behaviour stereospecific promoted by the D1 agonist R-SK \& F 38393 and selectively blocked by the D1 antagonist SCH 23390. Psychopharmacology 82:409-410.

Moody TW, Merali Z, Crawley JN. 1988. The effects of anxiolytics and other agents on rat grooming behavior. Ann NY Acad Sci 525:281290.

Mottola DM, Laiter S, Watts VJ, Tropsha A, Wyrick SD, Nichols DE, Mailman RB. 1996. Conformational analysis of D1 dopamine receptor agonists: Pharmacophore assessment and receptor mapping. J Med Chem 39:285-296.

Page SJ, Terry P. 1997. Conditioned grooming induced by the dopamine D1-like receptor agonist SKF 38393 in rats. Pharmacol Biochem Behav 57:829-833.

Parashos SA, Marin C, Barone P, Kapitzoglou-Logothetis V, Chase TN. 1990. Effect of chronic D-1 and/or D-2 dopamine antagonist treatment on SKF 38393-induced non-stereotyped grooming. Psychopharmacol 102:411-413.

Phillips GD, Howes SR, Whitelaw RB, Robbins TW, Everitt BJ. 1995. Analysis of the effects of intra-accumbens SKF-38393 and LY-171555 upon the behavioural satiety sequence. Psychopharmacol 117:82-90.
Piggins H, Merali Z. 1992. On the ontogenetic and sequential characteristics of bombesin-induced grooming in the infant rat. Dev Brain Res 67:247-256.

Poggioli R, Vergoni AV, Bertolini A. 1986. ACTH-(1-24) and alphaMSH antagonize feeding behavior stimulated by kappa opiate agonists. Peptides 7:843-848.

Randrup A, Munkvad I. 1974. Pharmacology and physiology of stereotyped behavior. J Psychiatr Res 11:1-10.

Richmond G, Sachs BD. 1978. Grooming in Norway rats: The development and adult expression of a complex motor pattern. Behav 75:82-96.

Robbins TW, Mittelman G, O’Brien J, Winn P. 1990. The neuropsychological significance of stereotypy induced by stimulant drugs. In: Cooper SJ, Dourish CT, editors. Neurobiology of stereotyped behaviour. Oxford: Clarendon Press/Oxford University Press, p 25-63.

Ruskin DN, Rawji SS, Walters JR. 1998. Effects of full D-1 dopamine receptor agonists on firing rates in the globus pallidus and substantia nigra pars compacta in vivo: Tests for D-1 receptor selectivity and comparisons to the partial agonist SKF 38393. J Pharmacol Exp Ther 286:272-281.

Segarra AC, Luine VN, Strand FL. 1991. Sexual behavior of male rats is differentially affected by timing of perinatal ACTH administration. Physiol Behav 50:689-697.

Sirkin DW, Zedek Y, Teitelbaum P. 1982. Snout contact fixation, climbing and gnawing during apomorphine stereotypy in rats from two substrains. Eur J Pharmacol 80:385-392.

Spruijt BM, Cools AR, Ellenbroek BA, Gispen WH. 1986. Dopaminergic modulation of ACTH-induced grooming. Eur J Pharmacol 120: $249-256$.

Spruijt BM, van Hooff JA, Gispen WH. 1992. Ethology and neurobiology of grooming behavior. Physiol Rev 72:825-852.

Starr BS, Starr MS. 1986. Differential effects of dopamine D1 and D2 agonists and antagonists on velocity of movement, rearing and grooming in the mouse. Implications for the roles of D1 and D2 receptors. Neuropharmacology 25:455-463.

Sullivan R, Dogaru C, Szechtman H. 1992. Constriction of environmental space and the behavioral response to the dopamine agonist quinpirole. Pharmacol Biochem Behav 43:1217-1219.

Trampus M, Ferri N, Adami M, Ongini E. 1993. The dopamine D1 receptor agonists, $\mathrm{A} 68930$ and $\mathrm{SKF}$ 38393, induce arousal and suppress REM sleep in the rat. Eur J Pharmacol 235:83-87.

Van Wimersma Greidanus TB, Maigret C, Torn M, Ronner E, Van der Kracht S, Van der Wee NJ, Versteeg DH. 1989. Dopamine D-1 and D-2 receptor agonists and antagonists and neuropeptide-induced excessive grooming. Eur J Pharmacol 173:227-231.

Vergoni AV, Poggioli R, Marrama D, Bertolini A. 1990. Inhibition of feeding by ACTH-(1-24): Behavioral and pharmacological aspects. Eur J Pharmacol 179:347-355.

Wachtel SR, Brooderson RJ, White FJ. 1992. Parametric and pharmacological analyses of the enhanced grooming response elicited by the D1 dopamine receptor agonist SKF 38393 in the rat. Psychopharmacology 109:41-48.

Watts VJ, Lawler CP, Gonzales AJ, Zhou QY, Civelli O, Nichols DE, Mailman RB. 1995. Spare receptors and intrinsic activity: Studies with D1 dopamine receptor agonists. Synapse 21:177-187.

Whishaw IQ, Dunnett SB. 1985. Dopamine depletion, stimulation or blockade in the rat disrupts spatial navigation and locomotion dependent upon beacon or distal cues. Behav Brain Res 18:11-29.

White FJ, Bednarz LM, Wachtel SR, Hjorth S, Brooderson RJ. 1988. Is stimulation of both D1 and D2 receptors necessary for the expression of dopamine-mediated behaviors? Pharmacol Biochem Behav 30:189-193.

Zhang SP, Zhou LW, Weiss B. 1994. Oligodeoxynucleotide antisense to the D1 dopamine receptor mRNA inhibits D1 dopamine receptormediated behaviors in normal mice and in mice lesioned with 6-hydroxydopamine. J Pharmacol Exp Ther 271:1462-1470. 